\title{
ياة العلامة أبو علي القالي وخدمته للغة العربية
}

\section{Hasan Morad ${ }^{1}$}

$$
\begin{aligned}
& \text { ملخص } \\
& \text { أبو علي القالي عالم وأديب من منطقة ديار بكر ولد ونشأ بها، سافر إلى بغداد وطال مقامه بها، وتلقى معظم علومه وآدابه } \\
& \text { هما، وسمع من كبار علمائها وأدباءها، كالأخفش الأصغر" ت.315هـ" وابن الأنباري" ت.328هـ"، وابن دريد" ت. 321هـ"، } \\
& \text { وغيرهم من العلماء الفطاحل في اللغة والأدب. استدعاه ملك الأندلس عبد الرحمن الناصر" ت.350هـ" إليها، فأكرم وفادته، } \\
& \text { وأحسن مقامه، وأفاض عليه بالعطاء. نقل أبو علي علوم المشرق من الأدب واللغة والأخبار والأشعار والدواوين إلى الأندلس، } \\
& \text { والتقى بعلمائها فأخذوا منه، واتخذوه إماماً وحجة، وأملى كتبه الكثيرة بها، فكان قدومه إليها يمثل فضة كبيرة في الدراسات } \\
& \text { اللغوية والأدبية. توفي أبو علي القالي بقرطبة بعد سنوات من العطاء المستمر، في سنة 356هـ، شهد له علماء عصره، وقرأوا } \\
& \text { عليه، واستفادوا منه، وأثنوا عليه بقصائدهم الكثيرة. } \\
& \text { الكلمات المفتاحية: القالي، الأدب، اللغة، الدراسات، ديار بكر. }
\end{aligned}
$$

\section{ÂLIM EBÛ ‘ALÎ EL-KÂLî’NIN HAYATI VE ARAP DİLİNE HİZMETí}

\section{$\ddot{O}_{z \text { et }}$}

Eb̂̂ 'Alî el-Kâlî Diyarbakır yöresinde doğup büyüyen edebiyatçı bir âlimdir. Bă̆dat'a gitmiş ve uzun süre orada ikamet etmiştir. İlim ve edebiyat bilgisinin büyük çoğunluğunu orada dil ve edebiyatta ileri derecede bilgi sahibi olan Ahfeş el-Asğar (v. 315), İbnü'l-Enbârî (v. 328), İbn Düreyd (v. 321) ve onlar gibi büyük alimlerden ögrenerek elde etmiştir. Endülüs hükümdarı Abdurrahman Nasır (v. 350) onu Endülüs'e davet edip kendisine misafirperver davranarak bol ikramda bulunmuştur. Eb̂̂ 'Alî, Doğu'nun dil, edebiyat, şiir, tarih ilimlerini ve divanlarını Endülüs'e taşımıştır. Oradaki âlimler yanına gelerek bu ilimleri ondan ögrenip kendisini önder ve hüccet kabul etmişlerdir. Ebû 'Alî eserlerinin çoğunu orada kaleme almıştır. Onun Endülüs'e gelişi dil ve edebiyat çalışmalarında bir reform olarak kabul edilmiştir. Yıllarca aralıksız ders verdikten sonra hicri 356 yılında Kurtuba'da vefat etmiştir. Çağdaşı olan âlimler onun bilgisine tanıklık edip, ondan ders alarak istifade etmiş ve pek çok kaside ile ondan övgü ile bahsetmişlerdir.

Anahtar Kelimeler: Ebû 'Alî el-Kâlî, Arap Edebiyatı, Dil Bilimleri, Araştırmalar, Diyarbakır.

\section{THE SCHOLAR ABU 'ALİ AL-KALI'S AND HIS SERVICE TO THE ARABIC LANGUAGE}

\begin{abstract}
Ebû 'Ali al-Kâlî is a literary scholar who was born and raised in Diyarbakir. He went to Baghdad and lived there for a long time. Most of his knowledge of science and literature was obtained by learning from great scholars such as Ahfeş el-Asğar (d. 315), İbnül-Enbarî (d. 328), İbn Düreyd (d. 321) and them, who had advanced knowledge in language and literature. Andalusian ruler Abdurrahman Nasir (d. 350) invited him to Andalusia and treated him hospitably and offered him plenty of treats. Eb̂े 'Alî brought the language, literature, poetry, historical sciences and divans of the East to Andalusia. The scholars there came to him and learned these sciences from him and accepted him as a leader and proof. Abu 'Alî wrote most of his works there. His arrival in Andalusia was considered a reform in the study of language and literature. He died in Cordoba in hijr 356 after giving lectures for years. Scholars who were his contemporaries witnessed his knowledge, benefited by taking lessons from him, and praised him in many odes.
\end{abstract}

Keywords: Eb̂̂ 'Alî el-Kâlî, Arabic Literature, Language Sciences, Research, Diyarbakır

1 Doktora Öğrencisi. Van Yüzüncü Y1l Üniversitesi Sosyal Bilimler Enstitüsü, ORCID ID: 0000-0001-9179574X, hsnmrad159@gmail.com. 
الحمد لله رب العالمين، وأفضل الصلاة وأتم التسليم على سيدنا محمد وعلى آله وصحبه أجمعين. وأما بعد: فإن منطقة ديار بكر خرجت منها كثيراً من العلماء الأفذاذ، الذين كانوا لهم باع طويل في العلم والأدب، وخاصة بعد الفتح الإسلامي لها، ومن هؤلاء العلماء إسماعيل بن القاسم أبو علي القالي صاحب الأمالي والنوادر والبارع وغيرها من الكتب النفيسة، التي قدمت غضة كبيرة في اللغة والأدب، وكانوا من قدموا بما لديهم من العلم والأدب خدمة عظيمة للغة العربية وآدابها وبلاغتها. فأردت أن أبين صفحات من حياة هذا العالم الجليل وما قام به من خدمة في اللغة العربية، ومنشأه ونسبه ومولده، وحياته العلمية، متمثلة في معرفة شيوخه، وتلاميذه، ومؤلفاته، ومعرفة ما قدمه من خدمة للغة العربية وآدابها، ودوره في تأسيس المدارس اللغوية في الأندلس، ونبذة عن بعض من الفوائد اللغوية في بعض كتبه، وبعض من أخباره ومدح العلماء له في أشعارهم، وكتبهم، وسنة وفاته، مبيناً ذلك كله بما منَّ الله علينا، ومعرفة ذلك من خلال الخطوات الآتية:

$$
\text { 1 . } 1
$$

أولاً: اسمه ونسبه ومولده: أبو علي القالي؛ هو إسماعيل بن القاسم بن عيذون، بن هارون بن عيسى بن محمد بن سليمان،

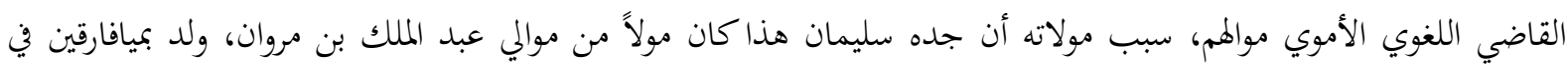
جمادى الآخرة لسنة مائتان و ثمانون للهجرة " 280هـ"، وهي جزء من أرض الجزيرة من ديار بكر، لكنه عندما انتقل إلى بغداد وصحب جماعة من أهل قرية قالي قالا "بين طرابزون ومنازجرد"، فانتسب إليها، وهي قرية من قرى منازكرد، من إقليم أرمينية، ويقال

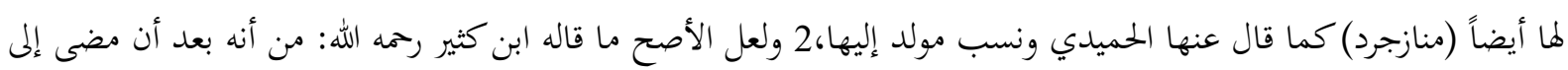
قرية قالي قالا، وسكنها فمضى عليه اسم القالي3. فيكون ميافارقين مولده ومنشأه، ومنازكرد منتسبه. ويؤكد هذا الرأي قوله عن نفسه عندما سأله أبو بكر محمد بن الحسين الزبيدي النحوي عن نسبه تحدث قائلاً:" عندما ابتهنا بغداد كنا في رفقة جماعة حيث كان فيها أهل قرية قالي قالا، وهي من قرى منازجرد وكانوا يكرمون لمكافم من الثغر، فلما دخلنا بغداد نسبت إلى هذه الجماعة لأفم، وجدوني معهم فثبت ذلك النسب عليَّ" ثانياً: نشأته: نشأ أبو علي القالي في منازكرد، ثم إنه رحل إلى بغداد سنة ثلاث وثلاث مائة "303هـ"، فأقام بالموصل، ثم دخل إلى بغداد سنة خمس وثلاث مائة"305هـ"، وأقام بها إلى سنة ثمان وعشرين وثلاث مائة "328هـ"، يكتب فيها الحديث، ثم سافر إلى الأندلس سنة ثلاثين وثلاث مائة "330هـ"، وبعدها إلى قرطبة في شهر شعبان لثلاث بقين منه سنة ثلاثين وثلاث مائة "330هـ "5. 2 . مسيرته العلمية: 2

\footnotetext{
الحميدي، أبو عبد الله بن أبي نصر، محمد بن فتوح، جذوة المقتبس في ذكر ولاة الأندلس، الدار المصرية للتأليف والنشر، القاهرة، 2

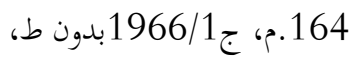

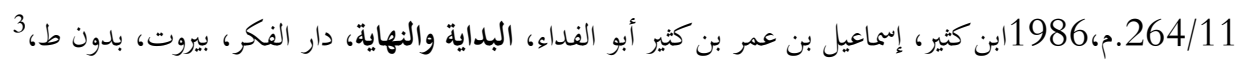

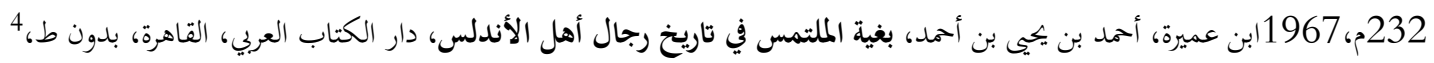

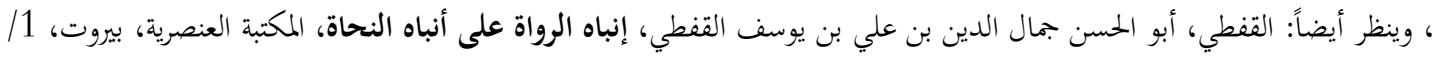

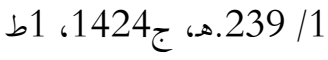

243.، 1/ 242القفطي، إنباه الرواة على أنباه النحاة، ج5
} 
سبق أن قلنا: إن أبا علي القالي رحمه الله نشأ في إحدى القرى التابعة لجزيرة ديار بكر، وارتحل منها إلى بغداد وسكنها وتعلم فيها، وذهب إلى غيرها من البلاد ابتغاء طلب العلم والمدارسة حيث التقى بكثير من العلماء والبلغاء وأخذ منهم العلم، وأخذوا منه، وصحب بعضاً من أهل بغداد في سفره إلى المغرب فدخل إليها أيام حكم الملك عبد الرحمن الناصر، واستوطنها، وكان ولده الأمير حكم بن عبد الرحمن، الملقب بأبي العاص أكثر ملوك الأندلس محباً للعلم، وأكثرهم عملاً به، وحريصاً عليه، فرحب به أيما ترحيب، وواجهه بالجميل، حيث أعجب به، وقرب منه، وبالغ في وفادته، وأحبه الحكم، وقيل؛ أنه أرسل إليه، ورغبه في اللجوء إليه ، والإقامة عنده، وكان ينشطه على التأليف ويوسع عليه في العطاء، ويشرح صدره بالإفراط في الإكرام، وكان أهل المغرب يلقبونه بالبغدادي لمجيئه من بغداد إليهم 6،أو لكثرة مكوثه في بغداد وإقامته بها. أما شيوخه وتلامذته فسنتعرف عليهم في الفقرة التالية: أولاً: شيوخه: سمع من عبد الله بن عبد العزيز البغوي أبو القاسم، ومن الحسن بن علي بن زكريا بن يجيى بن

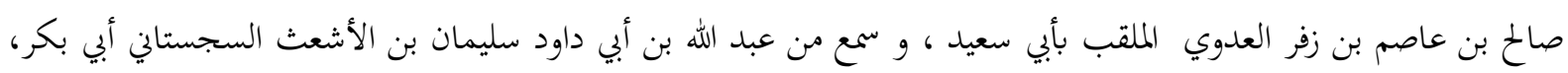
وتلقى الأدب عن محمد بن حسن أبي بكر بن دريد الأزدي، ومن محمد بن القاسم بن بشار المعروف بابن الأنباري الملقب بأبي

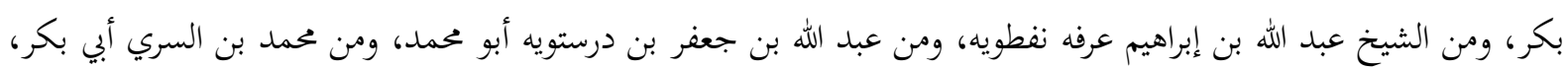
المعروف بابن السراج، ومن إبراهيم بن السري الزجاج أبو إسحاق، وأبي جعفر أحمد بن عبد الله بن مسلم ابن قتيبة، وأبي عمر الزاهد محمد بن عبد الواحد المطرز، علي بن سليمان الأخفش أبي الحسن، وغيرهم، وأخذ من أحمد بن علي بن المثنى (أبي يعلى) الموصلي الحديث7.

ثانيا: تلاميذه: أخذ عنه العلم كثير من طلاب العلم ونقلوا منه رواية ، منهم: عبد الله بن الربيع بن عبد الله التميمي الملقب بأبي محمد، و بن سعيد أحمد بن أبان، و محمد بن الحسن أبو بكر الزبيدي النحوي، صاحب كتاب مختصر العين وأخبار النحاة وكان في ذلك الوقت إماماً في الأدب، ولكنه عرف مقام العلامة أبي علي القالي فمال إليه، والتزم به، حيث استفاد من علمه وأقر له بالفضل، وأبو حيان النحوي، صاحب كتاب " المقصور والممدود" وابن الصناع، ومحمد بن عاصم المعروف بالعاصي وحكمم بن منذر بن سعيد والقزاز والقاضي ابن مغيث وآخرون8. ثالثا: مؤلفاته: كتاب" الأمالي" وكتاب" البارع في اللغة"، وكتاب " المقصور والممدود"، وله أيضاً " في الإبل ونتاجها" وله مؤلف؛

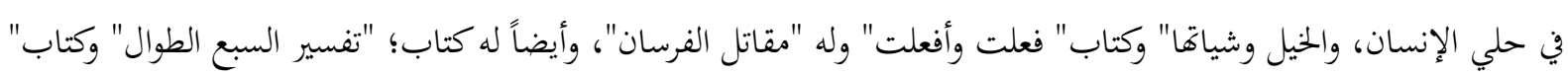
شرح فيه قصائد المعلقات"، وكتاب" حكايات أندلسية"، وله كتاب "تعليقات على شرح أدب الكتاب" لابن قتيبة، وله غيرها من الكتب، وفي قرطبة أملى كتابه "الأمالي" 9. فهذه بعض كتبه وسنأتي على تفصيلها وفيما ألفت لاحقاً. 3.

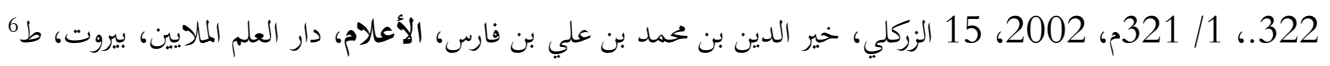

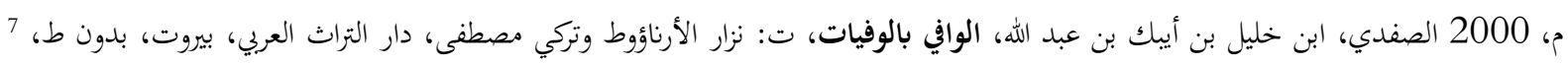

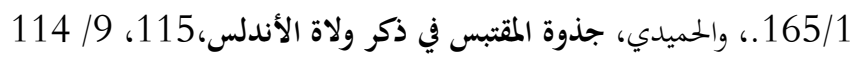

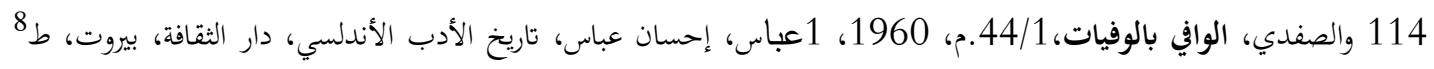 19،115 .

ابن خلكان، شمس الدين بن أحمد بن محمد بن إبراهيم بن أبي بكر، وفيات الأعيان وأنباء أبناء الزمان، تح: إحسان عباس، دار 9

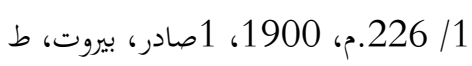


لقد مرَّ سابقاً أنه طال بأبي علي البقاء في بغداد لتلقي العلوم والمعارف، وكانت بغداد آنذاك تعج بالكثير من الأعلام والأدباء، وهذا ما فتح الطريق أمامه لكي يلتقي بهم ويأخذ عنهم ويعطيهم، وكانت بغداد ساحة الحوار والنقاش بين كلٍ من مدرستي الكوفة والبصرة، فأخذ من كلتا المدرستين، وإن كان كثير من المصادر تذكر تعصب أبو علي القالي للبصريين، فكان من العلماء والأدباء الحاذقين في العلوم العربية، وما تأدب ببغداد ووجد بأنه ليس له رزق في العراق، قصد بلاد المغرب العربي، فوافاها في

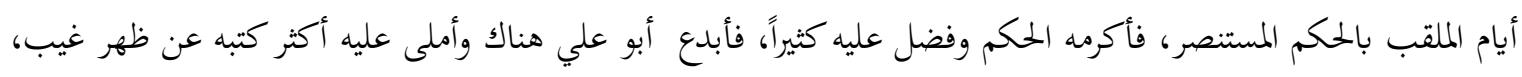
فمنها كتابه الأمالي، المعروف بين عامة الناس بفوائده الكثيرة، وهي غاية في معناه، قال ابن حزم أبو محمد: كتاب نوادر لأبي علي القالي مبارٍ للكتاب المبرد " الكامل" الذي جمعه صاحبه، فإن كان كتاب أبي العباس أكثره نحواً وخبراً ، فإن كتاب أبي علي القالي؛ أكثر لغة وشعراً، و تأليفه؛ "الممدود والمقصور" فإنه رتّبه على التفعيلة، وعلى مخارج الحروف من الحلق، مستقصى في بابه لا يغادر منه شيء في معناه، لم يؤلف مثله في بابه. وله" الإبل ونتاجها" وما تصرف معها، وكتاب" حلي الإنسان والخيل وشياتا"، وكتاب "فعلت وأفعلت"، وله كتاب" مقاتل الفرسان"، وكتاب" تفسير السبع الطوال"، وأما كتابه" البارع" في

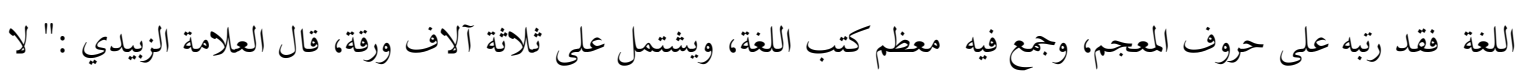
نعرف أحدا من المؤلفين القدامى ألّف على منواله، كما قال الشيخ الإمام ابن العربي: إن كتاب البارع لأبي علي القالي يضم أكثر من مائة جزء، ولم يصنف مثله في الإحاطة و الاستيعاب، فكان أعلم بنحو البصريين وأرواهم للشعر مع اللغة"10. وفي أيامه في الأندلس بث علمه هناك، وكان قد قرأ عن العلامة ابن درستويه كتاب سيبويه، ودقق النظر وانتصر للبصريين وأملى كتبه من حفظه 11. وهذا يدل على كثرة ما صحب معه من الكتب في هجرته إلى بلاد المغرب العربي، وما فيها من الدواوين العدد الكثير، وخاصة دواوين الجاهليين والأمويين والمجموعات الشعرية الهامة كالمفضليات، وشعر الهذليين والنقائض هني ومن هذه الدواوين التي أدخلها؛ منها دواوين الشعر: شعر عمرو بن قميئة، والحطيئة وشعر ذي الرمة، والنابغة الذبياني، وجميل وأبي النجم وعلقمة بن عبدة ، والنابغة الجعدي، وعروة بن الورد والمغيرة بن حبناء، والشماخ والأعشى، وكثير عزة وأوس بن حجر والقطامي والأخطل، وغيرهم كثير ممن ألف في دواوين الشعراء، كما انه أخذ معه كتباً كثيرة؛ في الأخبار والفنون

المختلفة12.

فكان يغلب بطبعه ميلاً إلى اللغة العربية وعلوم الأدب، فأبدع فيها، وأكثر في التأليف فيها، وكان علامة في علم اللغة بارعاً فيها، متقناً لها، فاستفاد منه الناس، ومالوا عليه، وأخذوه إماماً وحجة فيما نقله إليهم، وكانت كتبه في غاية من الإتقان والتقييد والضبط، كما ألف في علمه الذي اشتهر به واختص فيه من تأليفات مشهورة، تدل على سعة روايته، وكثرة إشرافه، وكتابه" النوادر" يتضمن فيه من الأخبار والأشعار واللغة13. 4 ـ نبذة من الفوائد اللغوية في بعض كتبه

\footnotetext{
نقلاً عن الحموي، أبو عبد الله شهاب الدين بن ياقوت بن عبد الله، معجم الأدباء، ت: إحسان عباس، دار الغرب الإسلامي، بيروت، 10

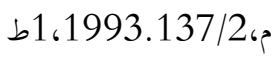

226.، وابن خلكان، وفيات الأعيان وأنباء أبناء الزمان، 1/ 9/ 114ينظر الصفدي، الوافي بالوفيات، 11

45/1. د. إحسان عباس، تاريخ الأدب الأندلسي، 12

165/1.، والحميدي، جذوة المقتبس في ذكر ولاة الأندلس، 115، 95/ 15/ 114الصفدي، الوافي بالوفيات، 13
} 
عرف العلماء القدماء قدر كتاب "النوادر"، وقدموه كما يقول ابن خلدون: " إن أصول وأركان هذا الفن؛ أربعة دواوين وهي: أدب الكتاب لابن قتيبة، وكتاب "الكامل" للمبرد، وكتاب البيان والتبين للجاحظ "وكتاب النوادر لأبي علي القالي البغدادي، وما سوى هذه الأربعة فتبع لها وفروع عنها"14. أما كتاب الأمالي فقد نقل أشعار العرب وأخبارهم وكان عمدة في اللغة والأمثال، وفيه شواهد من القرآن والحديث الشريف وتفسيرها، فيعد من كتب اللغة بامتياز، ويمتاز بفصاحة لغته فيذكر اشتقاقات الألفاظ وتصريفاقا، فقد التمس الصحة والسلامة في الفصاحة من خلال ألفاظ عند الجاهليين والإسلاميين، فكثيراً ما يستشهد بالقرآن فمن ذلك قوله: "والردء: العون، قال الله تعلى في محكم كتابه: : القصص: 34]"15، وبالنسبة للسنة المطهرة فمن ذلك في معنى العرض وأنه يأتي بمعنى الجسد مستدلاً بالحديث قائلاً:" عرضه:

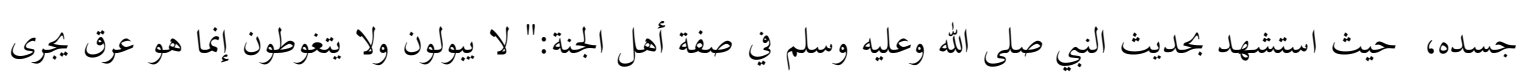
من أعراضهم مثل المسك يعنى من أبداظم" 16. و بأمثال العرب وهو كثير، مثلاً؛ قال:" وقال الأصمعي: من أمثال العرب: ذكّرئ الطّعن وكنت ناسياً، يضرب مثلاً للرجل يسمع الكلمة فيتذكر بها شيئا"17. ويستشهد بالدرر من الشعر العربي كقوله:" والأبلق لا ينتج، والعرب أخذوا هذا ضرباً للمثل لشيء لا ينالونه فيقولوا:

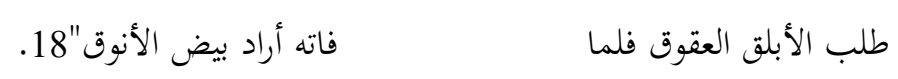

وأما بالنسبة للغة فإنه يستعمل الترادف والألفاظ المشتركة وقد يعالج اللفظة الواحدة ويصحح الأخطاء، ويستعمل التضاد في

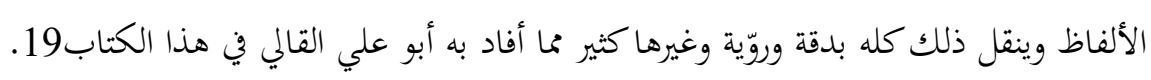

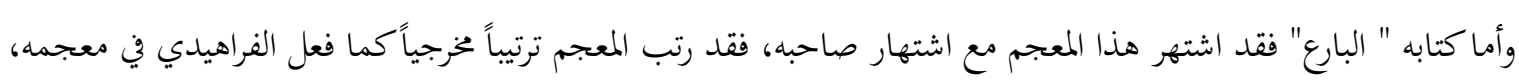

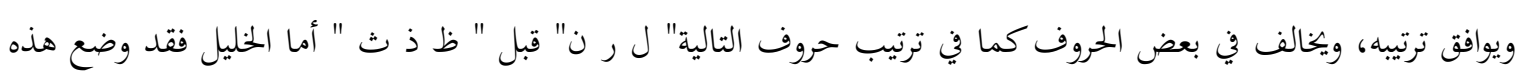
الأحرف بعد" ظ ذ ث" وكذلك القالي وضع " ط د ت " قبل "ص ز س" مخالفاً الخليل، وهذا المعجم يعد أول معجم ظهر في الأندلس، ويكفي ثناء عليه من تلميذه أبي بكر الزبيدي القائل:" إن هذا القاموس واسع يشمل اللغات كلها" أي اللهجات، وذكر العلامة الزبيدي أن كتاب البارع فاق كتاب العين بأربعمائة"400" ورقة، كما أن أبو علي القالي ذكر فيه بعض أصول حيث وضّح أها مستعملة، وكان الفراهيدي في كتاب العين قد قال: أها مهمله. ومن العلماء القدرين الذين أثنوا على كتاب البارع منهم الإمام السيوطي حيث قال: "إن من أصح القواميس التي رأيتها البارع للقالي وموهب للقيانن. ولكن اللغويين

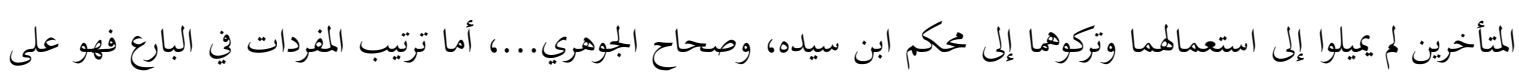

ابن خلدون، عبد الرمن بن محمد بن محمد، ديوان المبتدأ والحبر في تاريخ العرب والبربر ومن عاصرهم من ذوي الشأن الأكبر، 164، 14 1988،

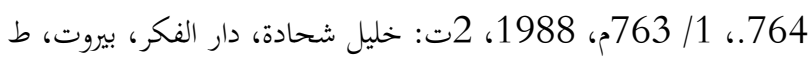

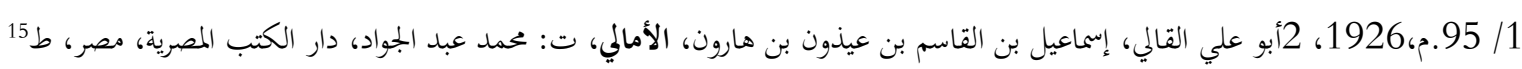

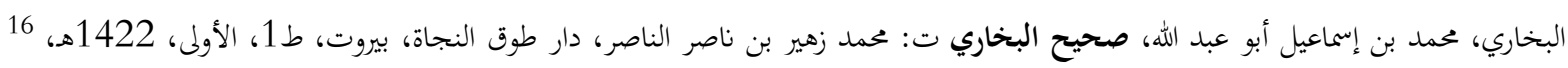

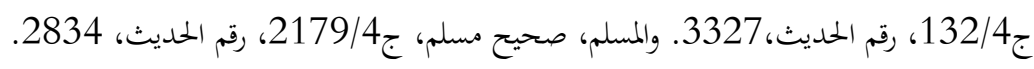

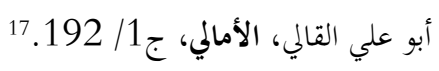

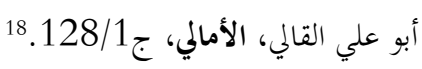

232.. 227م، ص 2005، سنة 23حمادة، مثنى يوسف، قراءة لغوية في كتاب الأمالي لأبي علي القلي، بجلة الفتح، ع: 19 
وجه الإجمال كترتيب العين مع مراعاة التقليبات، والأبجدية الصوتية، وتقسيم الكلمات من حيث الكمية "العدد الحروف" إلى ثنائي وثلاثي، ورباعي وخماسي. ولكن ترتيب الأبجدية الصوتية عند القالي لا يتفق تماماً مع أبجدية الخليل، ولكن يختلف عنها اختلافًا قليلاً. وبمقارنة الترتيبين هكذا يمكن معرفة مدى ارتباطهما" 20.

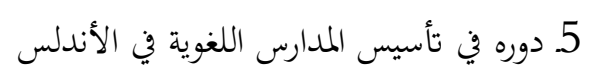

كان قدوم العرب إلى الأندلس بتراثهم الأدبي الأصيل دور كبير في فتح الأفاق أمام الأدباء فيها، فقد امتزج أدب المشرق بالمغرب وبطابع جديد، بطابع أندلسي، وقد ساعد في بناء المدارس اللغوية، حب الحكام في الأندلس للعلم، فقد مرَّ سابقاً أن الناصر وابنه الحكم شجعا العلماء والأدباء في القدوم إلى الأندلس وكان ممن دعاهم الناصر أبو علي القالي، فأكرم وفادته، وجعله مؤدباً لابنه الحكم، فنهضت الأندلس علمياً في كافة ميادين العلم والأدب. أما أبو علي القالي رحمه الله كان ممن تثقف ثقافة واسعة في المشرق، وعاصر كبار علماء اللغة، وأخذ منهم كأمثال ابن دريد والأخفش، فجمع بين اللغة والشعر والأخبار، فعندما قدم الأندلس وسكن القرطبة نشر علمه بها فلجأ إليه الناس وسمعوا منه وأخذوا عنه و تأثروا به، وحمل معه أيضاً الكثير والكثير من أدب المشرق متمثلًا في دواوين امرئ القيس وزهير

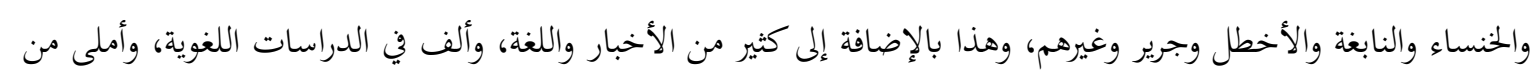
حفظه على طلبته الأندلسيين. كما أن مساجد الأندلس أصبحت مركزاً لحلقات دروس ومحاضرات لأبي علي القالي، وأقبل عليه أهل الأندلس للتعلم والتأدب، فكان يلقي في المسجد الجامع بالزهراء في القُرطبة دروسه كل يوم خميس، وكان أبو علي القالي واسع العلم في باب الأدب واللغة، وهذا مما شهد له علماء عصره، وسمعوا منه و قرأوا عليه، فاستفادوا منه كثيراً. فكان مجيء أبو علي القالي إلى المغرب الغربي؛ يمثل فضة كبيرة في المؤلفات اللغوية والأدبية، لذلك اتخذوه حجة فيما ينقل وعولوا عليه 21.

\section{. أقوال بعض علماء اللغة في مدحهة}

$$
\text { قال الأمير منذر بن سعيد البلوطي أبو الحكم، لقد كتبت إلى أبي علي القالي أستعير منه كتابا من الغريب، }
$$

وقلت:

$$
\begin{aligned}
& \text { بحث ريم مهنهف وصدغه المتعطف } \\
& \text { ابعث إليَّ بجزء من الغريب المصنف }
\end{aligned}
$$

نقضى حاجتي وأجابني بقوله من الجمتث:

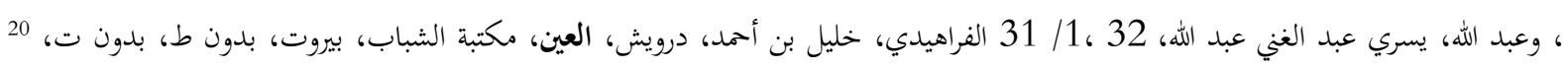

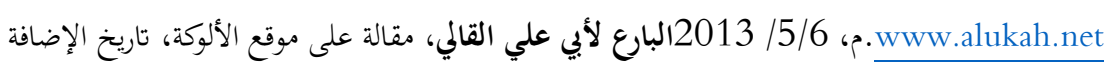

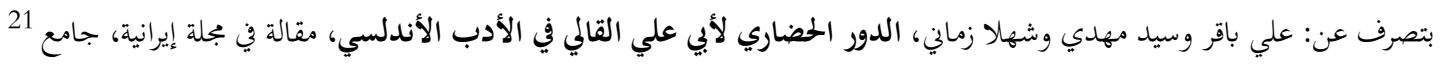

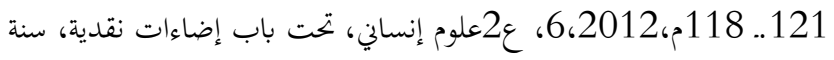




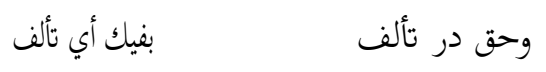

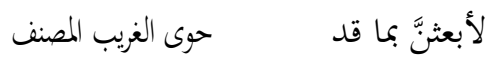

$$
\begin{aligned}
& \text { ولو بعثت بنفسي إليك ماكنت أسرف }
\end{aligned}
$$

ومدحه ابن هارون يوسف الرمادي بما يأتي ذكره في بابه من الحرف بقصيدة أوها من الكامل:

$$
\text { من حاكم بيني وبين عذولي } \quad \text { إن قلت الشجو شجوي والعويل عويلي }
$$

تم خرج من ذلك إلى مدح أبي علي القالي قائلاً:

$$
\begin{aligned}
& \text { روض تعاهده السحاب كأنه متعاهد من عهد إسماعيل }
\end{aligned}
$$

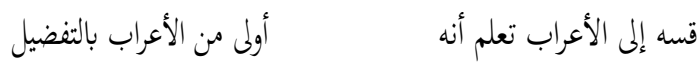



$$
\begin{aligned}
& \text { فالشر خال بعده وكأنه ما نزل الخراب بربعه المأهول }
\end{aligned}
$$

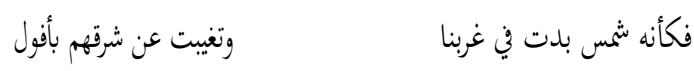

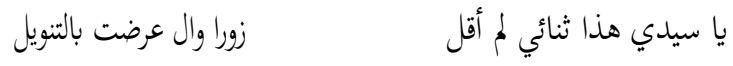

$$
\begin{aligned}
& \text { من كان يأمل نائلا فأنا امرؤ م أرج غير القرب في تأميلي }
\end{aligned}
$$

\section{7: وفاته رحمه الله تعالى}

توفي أبو علي في مدينة قرطبة في شهر ربيع الآخر، وقيل: كان وفاته في جمادى الأولى، سنة ثلاث مائة وستة

هـ" ليلة السبت في السادس من الشهر المذكور، وصلى عليه العلامة الجبيري أبو عبد الله. ودفن بمقبرة "356وخمسين متعة في مدينة قرطبة، رحمه الله تعالى 23.

وقال المقري:" بعض المؤرخين يزعمون أن قدوم أبو علي القالي إلى الأندلس، كان في خلافة السلطان الحكم

المستنصر بالأندلس، وليس في الخلافة السابقة؛ أي أبيه الناصر، والصواب أن قدومه في أيام السلطان الناصر، هذا ما

22 115/9 115 الصفدي، الوافي بالوفيات $227 / 1$

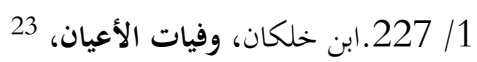


قاله أكثر من واحد من المؤرخين انه ارتحل عليه الكلام، أي" حصره وعيه" عندما كان يخطب في الاحتفال الذي أقامه الحكم الناصر لقدوم رسول الإفرنج عليه كما ذكرناه في مكان آخر غير هذا المكان"24.

وقد قال ابن خلكان:" ودخل أبو علي القالي إلى قرطبة السابع والعشرون من شعبان سنة ثلاث مائة ه"، وهو مما يدل على أن قدومه كان في أيام السلطان ناصر، وليس في أيام ابنه السلطان الحكم، وقد 330وثلاثون " ذكر ذلك الصفدي في كتابه الوافي قائلاً:" عندما دخل أبي علي القالي الأندلس قصد سلطان الأندلس ناصر الدين بن عبد الرحمن، فأكرم وفادته، حيث كتب له ولابنه الحكم تصانيف، ومؤلفات نشر علمه في المغرب العربي (الأندلس)"25. الخاتمة

لقد طفت في حدائق من كتب التراجم والتاريخ والأدب لأتزود من رحيق سيرة الإمام أبي علي القالي، فوجدةما مليئة بما ينعش الفؤاد، ويريح النفس، وأخذت منها خالصة مما يمكن أخذه، وقد توصل بي البحث إلى النتائج التالية:

- أبو علي القالي هو إسماعيل بن القاسم اللغوي القاضي الأموي، ميافارقين مولداً ومنشاً، القالي والبغدادي منتسباً، ولد سنة ثمانين ومائين، نشأ وعاث في بداية عمره في إحدى القرى التابعة لجزيرة ديار بكر، ثم انتقل بعدها مع بعض من أهل قالي قالا إلى بغداد، وطال به المقام في بغداد، تلقى معظم علومه وآدابه بها.

- سمع أبو علي القالي من كبار علماء والأدباء كأمثال: البغوي، والعدوي، وأبي داود السجستاني، وابن دريد، وابن الأنباري، ونفطويه، وابن درستويه، وابن السري، وابن السراج، والزجاج، وابن قتيبة، ومحمد المطرز، والأخفش، وأبي يعلى الموصلي، وغيرهم، وسمع منه جماعات كثيرة، وحدثوا عنه كأمثال: ابن التميمي، وابن أبان، ومحمد بن الحسن الزبيدي النحوي المشهور، وابن الصناع، والعاصي، والقزاز، وابن مغيث، وغيرهم.

- ألّف أبو علي القالي كتباً كثيرة في اللغة والأدب والأخبار منها: كتاب الأمالي، والنوادر، والبارع، والمقصور والممدود والمهموز، ومقاتل الفرسان، وتفسير السبع الطوال، وغيرها، فالأمالي كان كثير الفوائد غاية في معناه، والنوادر كان مبارياً لكتاب الكامل للمبرد، فهو أكثر لغة وشعراً، والمقصور لمم يوضع مثله في بابه، والبارع معجم لم يؤلف مثله في

\footnotetext{
المقري، شهاب الدين بن أممد بن محمد، نفح الطيب من غصن الأندلس الرطيب، وذكر وزيرها لسان الدين بن الخطيب، ت: 24

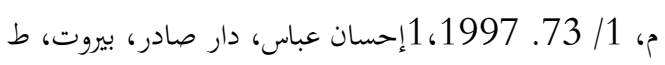

1/ 227. وابن خلكان، وفيات الأعيان، 19/ 115. ينظر الصفدي، الوافي بالوفيات، 25
} 
الإحاطة والاستيعاب، هذا وغيره مما نقله أبو علي القالي من بلاد المشرق إلى الأندلس معه، وأملى هما على طالبه، فكان أبو علي القالي بحق مدرسة - جامعة بين علم البصريين والكوفيين- بحد ذاته نقل علوم المشرق إلى بلاد الأندلس وما فيها من الدواوين الجاهليين والأمويين والمجموعات الشعرية الهامة والأخبار والفنون المختلفة. - كان أبو علي القالي ميالاً بجبلته إلى اللغة العربية وعلومها وآداها، فأبدع فيها، وأكثر منها، فأصبح علامةً في علم اللغة العربية بارعاً مبدعاً فيها، متقناً وضابطاً لها، فأخذ منه الناس واستفادوا منه، وعولوا عليه، وأخذوه إماماً، وحجة لهم، حيث كانت مؤلفاته غاية في الضبط والإتقان، والتقييد. فكان قدومه إلى الأندلس يمثل غضة كبيرة في الدراسات اللغوية والأدبية. - توفي أبو علي القالي بقرطبة بعد سنوات من العطاء المستمر من الدروس، والمحاضرات في مساجد الأندلس، ه، مما شهد له علماء عصره، وقرأوا عليه، واستفادوا منه، وأثنوا عليه بقصائدهم الكثيرة، فرحمه الله 356ووفاته سنة تعالى من عالم ملأ على الناس بالعلم والأدب والشعر. 


\section{المصادر والمراجع}

هـ، ديوان 808. ابن خلدون، أبو زيد عبد الرحمن بن محمد بن محمد، ولي الدين الحضرمي الإشبيلي، توفي:

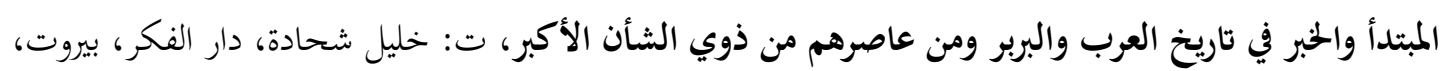

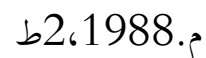

• ابن خلكان، أبو زيد شمس الدين بن أحمد بن محمد بن إبراهيم بن أبي بكر، أبو زيد ابن خلكان البرمكي

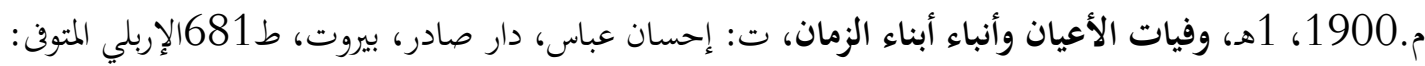

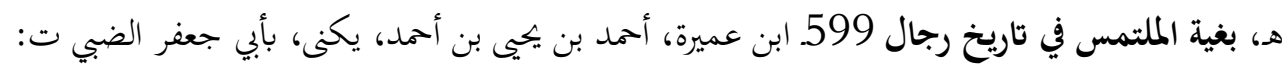

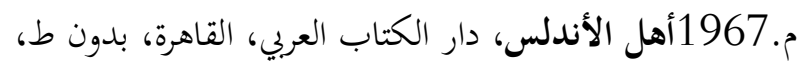

هـ، البداية والنهاية، دار 774. ابن كثير، إسماعيل بن عمر بن كثير أبو الفداء، القرشي البصري توفن:

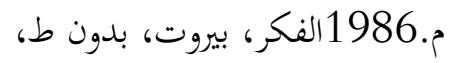

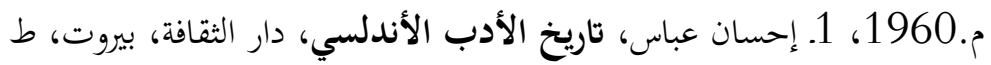
2005

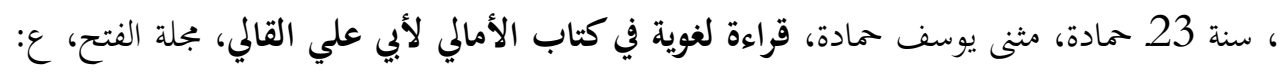

هـ، معجم 626. الحموي، أبو عبد الله، شهاب الدين بن ياقوت بن عبد الله الرومي الحموي المتوفى:

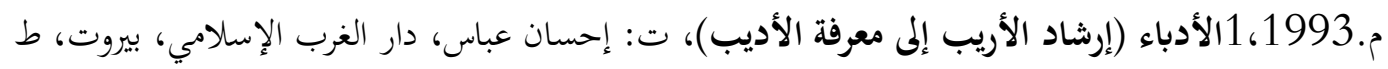

الحميدي، أبو عبد الله بن أبي نصر، محمد بن فتوح بن عبد الله بن فتوح بن حميد، الأزدي الحميدي المتوفى:

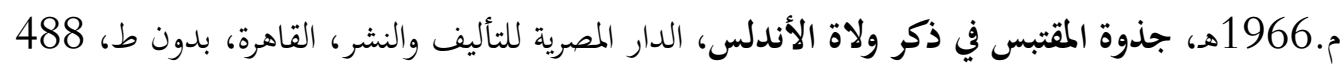



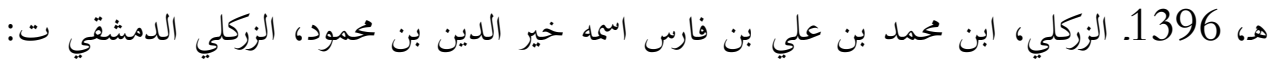

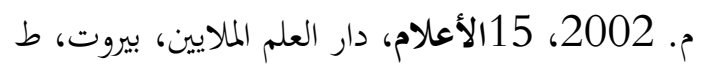

هـ، الوافي بالوفيات، 764 ـ الصفدي، ابن خليل بن أيبك بن عبد الله الصفدي، اسمه صلاح الدين توفي:

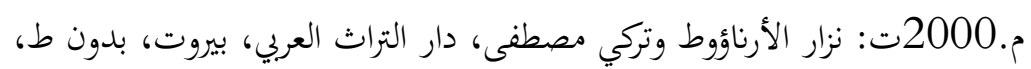

هـ، الأعلام، 1396. الزركلي، خير الدين بن محمود بن محمد بن علي بن فارس، الزركلي الدمشقي المتوفى:

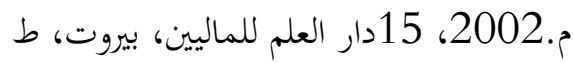

عبد الله، يسري عبد الغني عبد الله، البارع لأبي علي القالي، مقالة على موقع الألوكة، تاريخ الإضافة $2013 / 5 / 6$ ، . . . . .

ـ علي باقر وسيد مهدي وشهلا زماني، الدور الحضاري لأبي علي القالي في الأدب الأندلسي، مقالة في

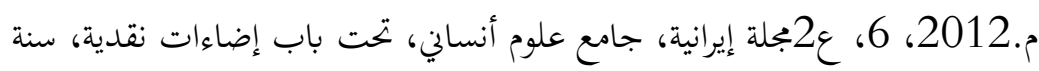

هـ، 356 القالي، أبو علي؛ إسماعيل بن القاسم بن عيذون بن هارون بن عيسى بن محمد بن سلمان توفي:

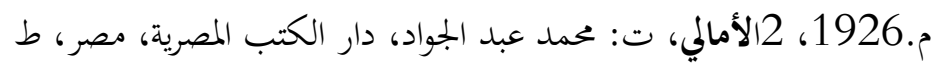

هـ، إنباه الرواة على أنباه النحاة، 646. القفطي، أبو الحسن جمال الدين بن علي بن يوسف، المتوفى:

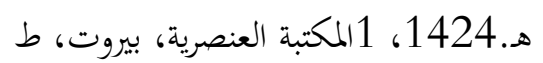


هـ، نفح الطيب من غصن 1041. المقري، ابن محمد المقري التلمساني أسمه شهاب الدين بن أحمد، توفي:

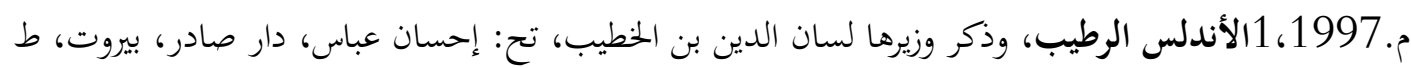

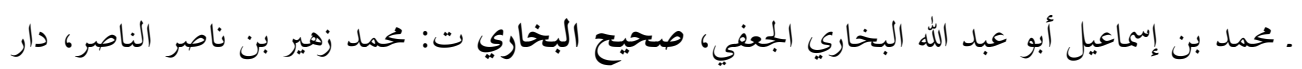

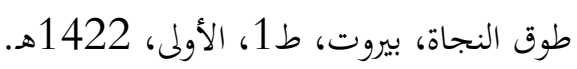




\section{GENIȘLETIMISS ÖZET}

Diyarbakır yöresi, ilçe ve çevre vilayetleriyle özellikle İslam fetihlerinin ardından, birçok âlim ve edîbin yetiştiği bir yer olmuştur. Bu yöreden çok sayıda âlim ve edîp çıkmıştır. İlim ve edebiyatta köklü bir geçmişe sahip olan bu âlimlerden biri de başta El-Emâlî, enNevâdir ve el-Bâri ' olmak üzere daha bir çok eserin müellifi olan Ebû 'Alî İsmâ'îl b. el-Kâsım el-Kâlî el-Bağdâdî’ dir. Ona ait kitaplar gerek dil gerekse edebiyatta yeni bir yükselişe öncülük etmesi bakımından kaynak eserlerdir. Bu eserleriyle Ebû 'Alî el-Kâlî, ilmî ve edebî açıdan Arap diline ve belagatına büyük hizmetlerde bulunmuştur.

Ebû 'Alî el-Kâlî, aslen Diyarbakır yöresindendir. Hicri 280 yılının Cemaziyelâhir ayında Meyâfarkin'de (Silvan'da) doğmuş ve yine Diyarbakır'ın Dicle-Fırat arasında bir konumu olan bu yerde büyümüştür. Daha sonra Trabzon ve Malazgirt arasında olduğu söylenen, Ermeni yerleşkesi sayılan Malazgirt köylerinden biri olan Kâlî köyünden gelen bir grup insana katılarak, onlarla beraber Bağdat'a yolculuk yapmıştır. Bağdat'a geldiğinde ise uzun bir süre (h. 303 yılına kadar) burada ikamet etmiş daha sonra Musul'a yerleşmiştir. Bir süre sonra tekrar (h. 328 senesine kadar) Bağdat'ta ikamet etmeye başlamıştır. Bu arada ilim öğrenmeye devam etmiş ve ilim tahsili amaciyla diğer memleketlere gitmiştir. Buralarda pek çok âlim ve ediple tanışıp onlardan ilim öğrenmiş ve hadis yazmıştır. Ahfeş, Enbârî, İbn Dûreyd gibi dil ve edebiyatta alanında üst düzeyde bir yeri olan âlimlerden ders almıştır.

Ebû 'Alî el-Kâlî'nin hocaları arasında şunlar bulunmaktadır: Ebû Kâsım Abdullah b. Abdülaziz el-Bağavî, Ebû Said lakabıyla anılan el-Hasan b. Ali b. Zekeriya b. Yahya b. Salih b. Asım b. Zafer el Adevîye, Ebû Bekir Abdullah b. Ebî Davûd Süleyman b. el-Eş'as esSicistanî ile yine Sicistânî'nin talebeleri de yanlarında ilim tahsil ettiği hocaları arasında anılabilir. Diğer yandan onun talebesi olup ondan birçok ilimleri alan alimler de bulunmaktadır. Başta Abdullah et-Temimî b. Said Ahmed b. Aban ve Muhammed b. el-Hasan Ebû Bekir ezZubeydî en-Nahvî'nin de dahil olduğu çok sayıda ilim talebesi ondan rivayet nakledenler arasında bulunmaktadır.

Yazmış olduğu eserlere gelince, El-Emâlî adlı kitabı bilinen en meşhur eseridir. ElEmâlî onun Endülüs'te vermiş olduğu ders notlarını içermektedir. El-Bâri 'fi'l-luğâ Endülüs'te yazılmış olan ilk sözlüklerden biri olma özelliğine sahiptir. El-Maksûr vel-memdûd eseri ise maksûr ve memdûd isimleri gösteren bir sözlük olarak temayüz etmiştir. Onun bu kitapları bilinen ve okunan kaynaklar arasında yer almakta ve sıkça referans kaynağ 1 olarak kullanılmaktadır. Bunların yanında Tefsirü's-seb'a ve Tefsîrü'l-Kasâ'idi'l-Mu'allakât adlı eserleri cahiliye dönemi şiiri hakkında önemli birer kaynak oluşturma hüviyetini taşımakadırlar. Kitâbu hikâyeti'l-Endulusiyye adlı kitabı ve İbn Kuteybe'nin Edebü'l-Küttâb adlı kitabına yazmış olduğu Ta 'lîkât alâ Şerhi Edebi'l-Küttab adlı şerhi de öne çıkan çalışmaları arasında yer almaktadır. Ebû Ali'nin yazdığı eserler bunlarla sınırlı olmayıp başka eserleri de bulunmaktadır.

Ebû 'Alî el-Kâlî'nin yaşadığı dönemde Bağdat'ta Kûfe ve Basra gramer ekolleri/okulları arasında söyleşi ve tartışmaların yapıldığı bir münazara ortamı oluşturulmuştu. Çoğu kaynak Ebû 'Alî el-Kâlî’yi Basra ekolü mensupları arasında zikretmektedir. Ancak o her iki ekolden de ders almış, Arapça ilimlerde zeki ve parlak edebiyat alimlerinden biriydi.

Bağdat'ta iyi bir tahsil aldıktan sonra Irak'ta geçim sıkıntısının baş göstermesiyle oradan ayrılmaya niyet etmiştir. Bu nedenle Kuzey Afrika'ya yani Mağrib'e yönelmiştir. Bunun üzerine Ebû 'Alî el-Kâlî'yi, el-Hakem el-Müstensir unvanına sahip Endülüs emiri huzuruna çağırmıştır. Emir, ona cömertçe davranıp bol ikramda bulunmuştur. Onu iyi bir konuma yerleştirdikten sonra daha fazla öneri sunmuştur. Onu oğlu Hakem'e öğretmen yapmıştır. Ebu'l-'Âs lakabına sahip olan oğlu Hakem b. Abdurrahman, Endülüs'ün ilmi seven herkesten çok onunla amel eden ve ilme tutkulu bir emirdi. Ona karşı ayrıca bir hayranlığı vardı ve onu güzelce karşıladı ve son derece abartılı bir yakınlık göstermiş oldu. Hakem onu sevmişti. 
Yazma konusunda teşvik ederek, aşırı bir cömertlik ile onun kalbine ferahlık vermiştir. Faslılar Ebû 'Alî el-Kâlî'ye Bağdat'tan geldiği için El-Bă̆dâdî nispetini vermişlerdi.

Ebû 'Alî el-Kâlî dil, şiir ve divanlardan oluşan doğu ilimlerini Endülüs'e aktararak Endülüs'ün ilim ve edebiyatın her alanında ilmî olarak yükselmesini sağladı. Âlimler ile görüşmelerinde onlarla karşılıklı olarak bilgi aktarımı sağladı. Onu imam ve hüccet saymışlar, o da birçok kitabını onlarla beraber kaleme almıştır. Ebû 'Alî el-Kâlî'nin Endülüs'e gelişi dil araştırmaları ve edebiyat için büyük bir yükselişi temsil etmekteydi. Aynı zamanda beraberinde çok fazla doğu edebiyatını temsil eden İmruülkays, Zuheyr, Hansa, Cerîr ve daha birçok başka şairlerin divanlarını taşımıştı. Bunun yanı sıra ahbâr (Araplarla ilgili tarihi rivayetler) ve dil ile ilgili çalışmalara ilişkin yazılar telif etmiş ve bunları ezberleyen Endülüslü öğrencilerine onları yazdırmıştır. Ebû 'Alî el-Kâlî’nin Batı Mağrib'e gelişi; dilbilim ve edebi literatür açısından büyük bir kalkınmayı temsil eder. Bundan dolayı bir hüccet olarak kabul edilmiş ve kaynak olarak referans gösterilmiştir. Ebû 'Alî el-Kâlî yıllarca ara vermeksizin ilim yolunda hizmette bulunmuştur. Daha sonra Kurtuba'da 356/967 yılında vefat etmiştir. Kendi döneminin alimleri ona tanıklık etmiş, eserlerini okumuş, onlardan yararlanmış ve onun şiirlerinin çokluğuyla övünmüştür. 